\title{
The Value of Future Officers' Foreign Language Training for Participating in International Peacekeeping Operations
}

\author{
Lidiia L. Nanivska ${ }^{1}$, Susanna M. Pasichnyk ${ }^{1}$, Tetiana M. Serhiienko ${ }^{1}$, Oksana V. Shcherba ${ }^{1}$, \\ Yurii M. Yakimets ${ }^{2}$ \\ ${ }^{1}$ Foreign Languages and Military Translation Department, National Army Academy named after \\ Hetman Petro Sahaidachnyi, \\ 32 Heroes of Maidan Street, 79026, \\ Lviv, Ukraine. \\ ${ }^{2}$ Separate Structural Unit, Automobile and Road College of Lviv Polytechnik National University, \\ 2 Lychakivska street, 79008, \\ Lviv, Ukraine
}

Received: January 6, 2021. Revised: October 12, 2021. Accepted: December 3, 2021. Published: January 2, 2022.

\begin{abstract}
The article deals with providing future officers of the Armed Forces of Ukraine with foreign language training for participating in international peacekeeping operations. The purpose was to analyze specifics of foreign language training for international peacekeeping operations. The content and essence of future officers' foreign language training for participating in international peacekeeping operations were studied. Further, the state of future officers' foreign language training for participating in international peacekeeping operations in higher military educational institutions of Ukraine was determined and consequent proposals for improving the content of future officers' foreign language training for participating in international peacekeeping operations were elaborated. The main research methods were as follows: comparative, problem-based and retrospective information analysis; testing of cadets, surveying the officers of the Armed Forces, enhancing the pronunciation and articulation of cadets. The results of cadet testing showed the need to improve the content of future officers' foreign language training for participating in international peacekeeping operations. The survey of the officers serving with the Armed Forces of Ukraine confirmed the urgent need to provide foreign language training in higher military educational institutions of Ukraine. According to the results of various survey forms applied, the main ways to improve the content of the future officers' foreign language training aimed at participating in international peacekeeping operations were identified: the use of open training platforms, the use of information and communication technologies, use of mind mapping, situational tasks, interactive technologies.
\end{abstract}

Keywords-Foreign language training, future officers, international peacekeeping operations, the Armed Forces of Ukraine.

\section{INTRODUCTION}

A $\mathrm{n}$ important driver in shaping the foreign policy of any

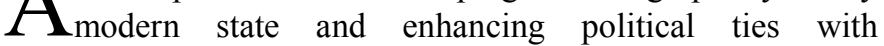
organizations such as NATO, the UN and the EU currently is the involvement of Ukrainian military personnel in international activities aimed at establishing peace and security worldwide.

The issue of preparing future officers of the Armed Forces of Ukraine for participating in international peacekeeping operations is given a close scrutiny in several areas of study [1]. When it comes to the philosophical perspective, the main focus is placed on the analysis and genesis of basic philosophical and ideological concepts and religious versions of peacekeeping, maintenance of peace and security [2]. In philosophy, peacemaking acts as a knowledge of another reality, as a way of resolving armed conflicts, an essential component of military policy, as a variant of crisis management [3]. Probing into the theoretical, methodological and socio-philosophical aspects of peacekeeping, scholars emphasize that the presence of UN peacekeepers in conflict areas should force the strong party to respect the rights of the weaker party and the latter to take into account the wishes of the former. Such contingents must act quickly and get it strong, which will enhance the peacekeeping war potential.

By estimates, 45,000 Ukrainian servicemen participated in international peacekeeping and security operations since 1992. Over the years, the number of the Ukrainian Armed forces' officers in particular missions, under different circumstances tended to vary according to the security settings in the areas where the international peacekeeping operations' tasks and requirements were performed. Currently, the Ukrainian Armed forces' officers participate in eight international peacekeeping and security operations in six countries and in the Abyei Area.

The integration of analytical materials makes it possible to 
validate that the high level of peacekeeping personnel's foreign language training (Ukrainian Armed Forces' officers) [4] is important for effective peacekeeping and security activities during international operations, which directly relates to the accomplishment of joint activities, communication, understanding, cooperation, crosscultural communication in the process of performing professional, socially significant responsibilities in a foreign language environment [5]. Taking into consideration the fact that peacekeeping operations are international in their nature, the effective foreign language training of future officers of the Armed Forces ensures deepening the professional cooperation between the contingent of the armed forces and army units participating in such events; with representatives of the Military Staff Committee of the UN Security Council; leadership of UN member states' armed forces contingents, etc. [6].

Having conducted the analysis of scientific works on the problem of providing foreign language training to the officers involved in international peacekeeping operations, the findings suggest the existence of philosophical [7], legal [8] as well as psychological and cultural [9] substantiation of such training.

In the works of [10], [11] and others the peculiarities of training officers for peacekeeping operations are examined. Theoretical and methodological approaches to training future professionals for foreign language communication as a means of effective intercultural interaction have been tackled as a relevant object of research [12], [13].

In general, when it comes to the intercompatibility of international operations to maintain peace and security, it primarily concerns hardware and software compatibility, military equipment and armament. By itself, such a connection shall without fail be combined with the interactional compatibility between people, processes and organizational components of peacekeeping activities [14]. The intercompatibility of human resources is frequently overlooked and presupposes tackling current problems successfully as a phenomenon that is taken for granted [15]. However, the requirements for the contemporary officer of the Ukrainian Armed Forces as well as the accelerated transition to NATO military standards place the process of future officers' foreign language training on a whole new level as compared to the previous years [16]. In these circumstances, foreign language training of the above specialists gains a broader significance, and it can be viewed within the framework of various spheres of officers' activity, the basis of which is their genuine readiness to perform functional duties according to specialty [17].

As shown by [18], servicemen's foreign language training underpins their professional readiness to perform a socially significant professional duty in international peacekeeping operations. The complexity of these phenomena confirms that systematic, systematic, consistent and comprehensive training for professional activity in a foreign language environment is extremely important to ensure the mentioned training of future officers of the Armed Forces of Ukraine to participate in international operations.
Over the last decade, the nature of international operations has changed significantly [19]. The process of establishing peace and security in the world has become much more complicated and requires the use of force in some regions. In such cases, force is used not only for self-defense. It is often necessary to enforce peace and use force to protect the civilian population, resolve regional conflicts, and provide humanitarian assistance (in the event of opposition from the local population or illegal military groups).

Restoration of peace and assistance in overcoming the consequences of transregional and local conflicts currently is an essential feature of international peacekeeping and security operations. According to the UN and regional security organisations, only compliance with the requirements of such a concept makes it possible to eliminate the conflict recurrence and helps to regulate the situation in the zone of conflicts and clashes. That said, peacekeeping tasks extend to cover the following: advising and supporting national governments on disarmament, demobilization and reintegration programs; assisting them in ensuring the safety of their citizens; support of their reforms in the national armed forces and police; economic and social reconstruction, etc.

As shown by the experience of international peacekeeping operations participants, there is a real threat of conflicts between servicemen from different countries participating in international operations, which fact can entail real danger in the performance of official duties, threaten the lives of the military. When it comes to this issue, it is expedient for us to talk about the need for servicemen to acquire skills of professional interaction and intercultural communication, to be in the know of ethnic groups' culture, ethical norms of behavior with foreigners. Therefore the training of future officers for participation in international peacekeeping and security operations is of great importance.

Ukraine's accession to the STANAG 6001 standard means that it accepts this standard with a view to harmonising the relevant requirements for the Ukrainian Armed Forces servicemen's language proficiency levels, who are appointed to serve their duty in the following positions: officers of multinational staffs (by areas of activity), military translators (onboard translators), military UN experts (military observers, staff officers and UN liaison officers), national contingent leaders, civilian cooperation specialists, military police officers and other specialists as required.

The Law of Ukraine "On Ukraine's Participation in International Peacekeeping and Security Operations" determines legal grounds for Ukraine to fully recognize its responsibility in maintaining international peace and security, has relevant obligations as a member state of the United Nations, and should therefore provide assistance to the UN in proceedings under the UN Charter, and collaborate meaningfully with the OSCE to prevent and resolve conflicts. In such a way, Ukraine contributes to the development of European and international collective security systems. Apart from that, the law stipulates that a multinational highly prepared military formation is a military formation consisting of forces and means of the armed forces of member states or 
partner states belonging to the relevant international organization and created to implement decisions of the UN Security Council, NATO and the European Council as well as other international organizations.

In order to properly perform the tasks of such missions, it is crucial for servicemen to develop their communication skills. This is one of the defining features of an efficient officercommunicator, as the main task of mission commanders, staff officers and officers-in-chief is to ensure that subordinates correctly execute their tasks and commands. This is to say that they shall be able to clearly and distinctly articulate the information in a foreign language, be able to work in a team. The well-formed foreign language competence, speaker's knowledge of the interlocutor's culture can help to understand that all participants in international peacekeeping operations are one team.

The future officers' increasing demand for foreign language training with the view to participating in international peacekeeping and security operations is discussed in a number of legal documents. In particular, the final report of the European Commission to the Directorate-General for Education and Culture on professional training requirements states that foreign language education is a mandatory and integral component of servicemen's training [20]. If a truncated version of the specific requirements for foreign language compenency of the Armed Forces officer should be offered, it is outlined as follows. When it comes to knowledge and understanding, these include methods of language learning, activity methods and tools; development of critical and cognitive approaches to teaching and learning; mastery of language; use of information and communication technologies in the pedagogical process; research skills; application of various assessment methods and methods of keeping records of cadets' educational performance. As for strategies and skills, these include as follows: the ways to adapt pedagogical approaches to the pedagogical situation and cadets' individual needs; critical assessment of the development as well as didactic material and teaching aids application; teaching methods; development of independence, reflective (reproductive) practice and self-esteem; ways to maintain and enhance life-long learning, research activity.

Given the above, the purpose of this article is to analyze the importance of foreign language training of future officers of the Armed Forces with the view of their prospective participation in international peacekeeping operations. The main tasks stemming from the stated purpose are as follows:

- to analyze the requirements for foreign language training of future officers of the Armed Forces for participation in international peacekeeping operations;

- to study the content and essence of foreign language training of future officers of the Armed Forces of Ukraine for participation in international peacekeeping operations;

- to elicit the state of foreign language training of future officers of the Armed Forces of Ukraine for participation in international peacekeeping operations in higher military educational institutions of Ukraine;

- to elaborate proposals as relate the improvement the foreign language training content for future officers of the Armed Forces with the view to their participation in international peacekeeping operations.

\section{Materials And Methods}

\section{A. Research Procedure}

The study of the problem and the sustained attention to providing foreign language training to future officers of the Armed Forces with the view to their participation in international peacekeeping operations took place on the basis of higher education institutions and higher military educational institutions of Ukraine, namely: the Military Institute of Kyiv Taras Shevchenko National University, Hetman Petro Sahaidachnyi National Ground Forces Academy. The choice of these institutions of higher learning is due to the fact that the research was carried on the basis of several institutions of higher education. The first of them was the Hetman Petro Sahaidachnyi Ground Forces Academy, on the basis of which the International Center for Peacekeeping and Security was established, designed to ensure the conducting of tactical, tactical-special, practical classes on the field training facility. This center conducts training sessions with cadets of the National National Ground Forces Academy, instruction of military units of the Armed Forces of Ukraine for operations as part of peacekeeping missions (forces), servicemen and employees of the Armed Forces of Ukraine, other military formations, law enforcement officers, peacekeepers and national contingents of Ukraine, foreign countries and international organizations. Representatives of these categories are trained to perform tasks related to their participation in the anti-terrorist and peacekeeping operations, train personnel of military units, detachments, coach trainees and cadets of other military educational institutions of the Ground Forces of the Armed Forces of Ukraine in accordance with training schedules. As regards the Military Institute of Kyiv Taras Shevchenko National University, in its structure there is a Linguistic Research Center. It is a scientific structural subdivision of the abovementioned educational institution, which carries out planning, organization, scientific and research activity, and also performs practical tasks concerning language support of Ukrainian Armed Forces.

An important stage in probing into this issue was to obtain permission from the heads of relevant departments, as the main respondents were current as well as future officers of the Armed Forces.

For our study of examining the state of foreign language training in the process of practical training in military institutions of higher learning as a basis for the readiness of future officers of the Armed Forces to participate in international training we can suggest three levels set forth by many researchers [21], [22] as evidence of possession of information to achieve a sufficient level, that is the level of "automated" communication:

the first level - the cadet is fully cognizant and has a clear picture of all the "planned" steps of the activity, can name the necessary sequence of steps, and the possibility of establishing 
these or other techniques depending on the language of instruction, but in person never carried out this activity;

the second level - ("knows - is capable") begins with the fact that the cadet, guided by the memo, a number of times carries out a technique (a set of techniques) of a learning activity checking up with the memo available at hand of recalling it from memory. In this case, the training will be more successful. As a result, the cadet is able to perform the corresponding technique, but will perform it realizing this process while diverting his arbitrary attention to the technical side of the task and therefore spending more time on the technique than necessary;

the third level - the level of technique mastery. The cadet, relying on clear perceptions about each subsequent stage, is not cognizant of the process of activity, the "automation" performs the technique or a series of learning techniques. This means that the cadet is not diverted by the technical side of the exercise, he hardly thinks about it. The technique is based on the level of a skill: the cadet mastered the technique.

\section{B. Basic Research Methods}

The first stage in addressing the problem under study was the use of comparative analysis of the content and state of officers' training to participate in international peacekeeping operations, as well as problem-oriented and retrospective research of philosophical, sociological, psychological, pedagogical scientific literature to elicit the extent of the previous investigation; identification of key research concepts; generalization and systematization of scientific stipulations in order to develop a concept and a system; analysis of the content of foreign language training programs for future officers; systematization of the obtained information on the research problem. The next step was to use the method of observation to analyze the cadets' pronunciation, their articulation, etc.

\section{Formation of the Research Sample}

1. In order to address the tasks set out in the work, we used the methods of testing and interviewing. Testing (in English at the proficiency level 2 in accordance with the international agreement STANAG 6001 on the level of foreign language proficiency of servicemen) was conducted with 30 cadets from the Academy of Ground Forces in the specialty "Philology" and 30 cadets from the Military Institute in the specialty "Philology" (military translation). The interview method was used with current officers, participants in international peacekeeping operations, who enrolled at the Ground Forces Academy for advanced training (the total number of officers was 19).

The criterion "x-square" was calculated by the formula:

$$
x^{2}=\left(f_{1}-f_{2}\right)^{2} /\left(f_{1}+f_{2}\right)
$$

where $f_{1}$ and $f_{2}$ - frequencies of the compared samples.

3 . The coefficient of combination of features is related to the chi-square as follows:

$$
C=\sqrt{\frac{x^{2}}{x^{2}+n}}
$$

\section{Instruments}

Google Forms was used for the survey. Data entry and processing was performed using "SPSS Statistics 17.0". All data are given in relative (\% of the number of respondents) values.

\section{RESULTS}

The expediency of any scientific research is to obtain reliable and complete information about an object, process or phenomenon [6]. In order to accomplish the study of the state of Armed Forces future officers' foreign language training for participation in international peacekeeping operations, it was decided to conduct diagnostics based on tests at the proficiency level 2 in accordance with the STANAG 6001 international agreement on soldiers' level of foreign language proficiency.

The developed tests included questions as for the main features of English at all hierarchical levels (phonetic, morphological, lexical, syntactic), rules for constructing affirmative, interrogative, imperative and exclamatory sentences, algorithms for the future officer of the Armed Forces in various extreme language situations during performing the peacekeeping tasks.

It was found that only a quarter of respondents were able to perform this task at a sufficient level. Questions about the peculiarities of the English language at the syntactic level, the algorithms of the future officer of the Armed Forces in various extreme language situations of professional activity proved to be fairly difficult for the cadets.

While the tests also contained the tasks aimed to determine how cadets know the grammatical constructions and their use, as well as modern terminology for weapons and equipment of the armed forces in countries that participate in international operations, what is the terminological minimum for professional communication in a foreign language. We also took into account cadets' knowledge of the peculiarities of dissemination the military, military-political and militarytechnical information, rules of documents registration and execution of records in English in accordance with the staff practice, knowledge of abbreviations and their meanings used in radiotelephone communication, radio exchange as well as in the daily interaction of international operations participants. Only a quarter of the surveyed participants were able to perform these assignments at a sufficient level. The overall test results distribution by percentage is as follows:

The National Ground Forces Academy of Ukraine, the total number of cadets is 25 people: $24.32 \%$ - the third level, $44.83 \%$ - the second level, 30.85\% - the first level (Fig. 1). The Military Institute of Kyiv National University, the total number of cadets is 30 people: $23.91 \%$ - the third level, $39.17 \%$ - the second level, 36.92\% - the first level (Fig. 2). A fragment of the test tasks is presented in Table 1. 


\section{TESTING RESULTS OF CADETS FROM THE NATIONAL GROUND FORCES ACADEMY OF UKRAINE (LVIV)}

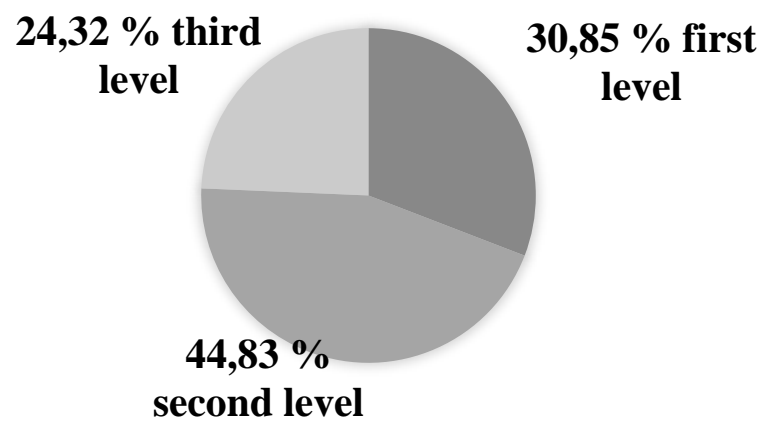

Fig. 1 Diagram with the results of testing cadets of the National Ground Forces Academy of Ukraine (Lviv)

\section{TESTING RESULTS OF CADETS FROM THE MILITARY INSTITUTE OF KYIV NATIONAL UNIVERSITY (KYIV)}

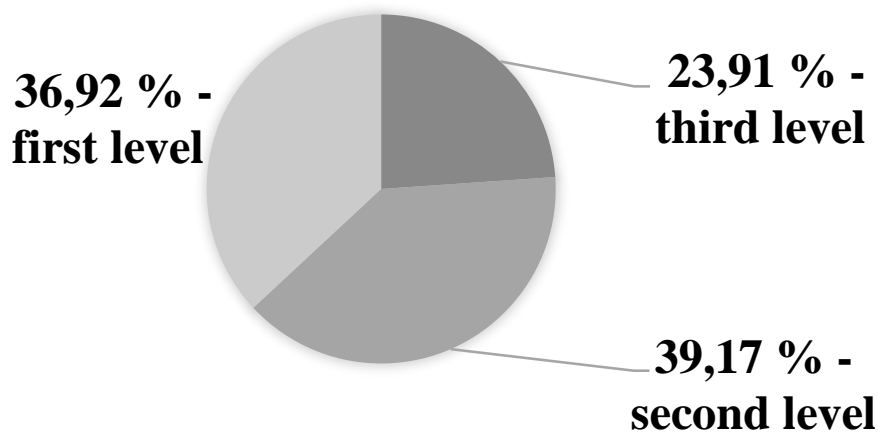

Fig. 2 Diagram with the results of testing the cadets of the Military Institute of Kyiv National University (Kyiv)

Table 1. Fragment of test tasks for cadets of the Land Forces Academy and the Military Institute.

1 The main goal of the foreign Armed Forces was

2 What was the start point of failure of theTaliban regime?

3 According to the text, in 2009 theterrorists

4 According to the text, on December 1,2009, U.S. President Barack Obama announced
A to target Taliban positions
B to find terrorists' leaders
C to conduct military training

A The fall of Kabul

B Heavy bombardment of terroristtraining grounds

C Bombardment of the tribal areas of Pakistan

A increased the amount of the insurgentsattacked the Independent

Human Rights

B Commission

$\mathrm{C}$ killed more than a half of the local population

A that the withdrawal would be lasting over aperiod of six months

B that an additional troops would be deployed

C that the war had been finished 
5 According to the text, the War inAfghanistan is
A the longest military conflict
B shorter than the War in Vietnam
C the shortest military conflict

The presented results (Fig. 1 and 2) confirm the need to improve the content of foreign language training of future officers of the Ukrainian Armed Forces to participate in international peacekeeping operations.

In order to elucidate the attitude of the Ukrainian Armed Forces servicemen's to a foreign language (English) and determining the meaningfulness of applying the language knowledge obtained at the military higher educational institution during the performance of tasks and international operations to maintain peace and security in the world, a survey was conducted. The additional survey also made it possible to identify the areas of concern in the study of a foreign language with the aim of further improving the foreign language syllabus. The anonymous survey provided an opportunity to identify problematic issues in the formation of their readiness for professional cooperation in international peacekeeping and security operations, their study of a foreign language and ways to enhanve the relevant disciplines.

It was found that all respondents had a general idea of the significance of a foreign language in international peace and security operations, the objectives of foreign language training and relevant knowledge, skills and abilities. One of the survey questions was about the respondents' participation in the AntiTerrorist Operation and the Joint Forces Operation. According to the data obtained, the percentage of such servicemen was $45 \%$ among officers (which is 9 people). Thus, out of 19 people, 10 servicemen $(52.63 \%)$ took part in international operations.

\section{A. Questionnaire to Determine the Understanding by the Servicemen of the Importance of Foreign Language Training in International Operations}

Please kindly answer the suggested questions.

How did you know that servicemen could take part in international peacekeeping and security operations?

1 - at the lessons

2- teachers shared their own experience

3- from colleagues participating in the Anti-Terrorist Operation / Joint Forces Operation

4- from the Internet

5- from my parents

6- your option

Do you know that every serviceman can take part in an international operation?

$1-$ yes

2- no

3- that's the first time I've got to know it

4- your option

Do you plan to take part in peacekeeping and security operations?

1 -Yes, I'm planning

2- No, I am not planning

3- I haven't considered it yet
Do you think that foreign language training is part of the compulsory training of a serviceman?

$1-$ yes

2- no

3- partially

4- your option

Does foreign language training play an important role in the daily activities of a serviceman participating in international operations?

$1-$ yes

2- no

3- I don't know

4- your option

What is foreign language training (in your opinion)?

What difficulties did you face during the foreign language training?

In your opinion, does foreign language training in your university fully meet the requirements of the Armed Forces for servicemen training?

1. yes

2. no

3. partially

4. does not answer

5. there is something to strive for

6. your option

Please provide a definition of "readiness for professional interaction": Your personal vision, interpretation (in short, no more than 5 lines).

Describe the concept of "foreign language readiness" (in short, no more than 5 lines).

Is it necessary to develop readiness for professional cooperation in international peacekeeping and security operations?

1. Yes.

2. No.

Please, substantiate your point of view.

A total of 19 people, namely $100 \%$ of the survey participants, acknowledged the urgent need for quality foreign language training to participate in international peacekeeping and security operations, that is an adequate level of foreign language proficiency for peacekeeping missions.

The findings showed that among servicemen there is an urgent need to master a foreign language. Among the interviewed officers, a higher rate of necessity to master a foreign language was found than among cadets. Such results can be explained by the fact that these officers were actually involved in international peacekeeping and security operations and in fact could practice their communicative skills with foreign colleagues, where English was the language of both interpersonal (private) and official communication.

Also in the questionnaire on foreign language training for the performance of their professional duties in the 
international military contingents, 12 officers considered it necessary to do the appropriate groundwork when learning a foreign language at the educational institution, making a point the lack of time to adapt to their professional, socially significant duty as part of international operations.

One of the questionnaire questions was to determine the list of professional competencies required for an Armed Forces officer to successfully perform his duties in international peacekeeping operations. The questionnaire is presented in Appendix A.

By the method of observation we studied the ability of the survey participants to pronounce English sounds correctly, to articulate words and phrases; read basic authentic literature on familiar topics (military), unambiguous texts that may contain descriptions of people, places and things; make up interrogative sentences on routine issues, work with a dictionary for a faster understanding of information and correct performance of tasks, clearly and concisely articulate ideas, conduct a spontaneous conversation, which contains extended additional messages, as well as evaluate information and express their views on the discussion, being able to justify the point (the statement should consist of at least 7 lines), select information and find specific information in more complex texts related to the professional scope of activity.

As regards the translation skills of future officers of the Ukrainian Armed Forces, attention was focused on the analysis of their ability to translate without consulting a dictionary from English into Ukrainian and vice versa the texts within the program language material; to perform grammatical transformations during translation, in case of difficulties to know how to apply generalization and descriptive translation; to render military-technical and military-special texts; to transform the content of the previously read or listened to English-language source of regional military topics to the level of one or two items, plan, summary; to find the necessary information in English in a compressed time frame.

Only about $43 \%$ of cadets in both the Ground Forces Academy and the Military Institute were able to perform these tasks at a sufficient (the second) level.

Thus, the results of the study showed the need to enhance the content of foreign language training of future officers of the Armed Forces with the view to their participating in international peacekeeping operations.

Taking into account the scientific advances, analysis of the scope and essence of professional activity to maintain peace and security makes it possible for us to claim that the readiness of future officers of the Armed Forces of Ukraine to participate in international operations to maintain peace and security can be considered a complex personal entity, which is needed to perform the professional, socially meaningful duties in a foreign language environment to ensure peace and security.

Analysis of the results of the "chi-square" showed that the confirmatory experiment confirmed the null hypothesis, according to which all groups (three experimental and one control) had no significant differences, as the value of $\chi_{\text {investigated }}^{2}$ is smaller than value of $\chi^{2}$ critical $(\mathrm{P}=0.9996)$ (Table $5)$.

Table 5. The value of the criterion "chi-square" when comparing groups by level of readiness for teamwork of students

$\begin{array}{ccccc}\text { HEI } & \begin{array}{c}\text { value of } \\ \chi^{2} \text { investigated }\end{array} & \begin{array}{c}\text { value of } \\ \chi_{\text {critical }}^{2}\end{array} & \begin{array}{c}\text { number of } \\ \text { freedom stages }\end{array} & \mathrm{P} \\ 1,2, & 0,28 & 12,58 & 6 & 0,9996 \\ 3,4 & 0,28 & 6 & \end{array}$

Source: Compiled by the authors based on the results of the study

Such indicators of the "chi-square" criterion indicate the validity and reliability of the study, and its results can be transferred to a more representative sample. But even the existing sample of respondents allows us to objectively investigate the question.

\section{DISCUSSION}

Our study initiates the issue of training Ukrainian officers in international operations, as well as the capabilities of certain technologies. The impact of technology and methods on foreign language training of officers in peacekeeping operations was not addressed by the above researchers.

The main takeaway message in comparing the present study with the existing ones is as follows: Ukrainian higher education institutions need to enhance the content of foreign language training, especially for future officers of the Armed Forces due to the fact that according to the Soviet paradigm, a higher education institution must first and foremost train an artilleryman, a tank soldier or a border guard, and their chosen specialization or even specialty is secondary.

The study of scientific issues related to the improvement of the learning process shows that in the course of learning a foreign language a very important role is played by increasing the motivation for its mastering by cadets of military universities. This thesis completely coincides with the conclusions of the study [5]

In modern conditions, there is a strong position of many scholars that motivation in learning a foreign language plays a decisive role. We can learn about this from the study [6]. However, this phenomenon is poorly studied and not recommended in modern methods of teaching a foreign language. Therefore, considerable attention should be paid to substantiating the conditions of effective motivation for the successful acquisition of English by cadets of experimental military universities. Such research results contradict the data presented in the article [8], where motivation issues are considered to be covered and resolved. Instead, the studies [9] and [12] confirm the data of this study.

It is well known that English serves as the main language of international negotiations and education at various levels. This thesis can also be found in the article [11]. However, the English language, as an academic discipline, should serve as a target setting for cadets for its enhanced mastery, the formation of correct skills and abilities of written and oral 
speech, increase military-professional orientation. As an important condition in the training of cadets of professionallyoriented English is the motivation to learn a foreign language in a military university. These data contradict the study [24] which propose to focus attention not on motivation, but on communicative competencies. Instead, the article [25] confirms the data obtained in the study.

Analysis of empirical material shows that the determining condition for learning English can be the formation of cadets the necessary semantic personal knowledge of professional speech [26]. The latter finds its indirect expression in the bias of their consciousness to certain aspects of it and is outwardly manifested in the focus, concentration and selectivity of attention in training: lectures, seminars, practical classes, business games in a foreign language, as well as in the emotional color of their reactions to offered educational information. The same opinion is shared by the authors of the article [27] but with regard to the Portuguese language.

The use of information and computer technology overall allows to maintain constant effective feedback with cadets, so teachers can partially adjust the training course, identify topics that need to be studied in more detail [28]. Learning a foreign language becomes more salient due to the perception pyramid of learning forms: after viewing and observing, cadets memorize more than $50 \%$ of the information [29]. Under such conditions, teachers have easier time facilitating group work, while maintaining the individualization of the educational process [30].

\section{CONCLUSION}

Virtually all modern states try to do their utmost and allocate maximum resources to the effective implementation of their foreign policy. Given that there are many "troubled regions" in the world, the global community is trying to resolve conflicts. Whereas diplomacy is not always successful so peacekeeping operations should be held. Only effecient specialists can take part in such operations. The training of such specialists is a complex issue, and one of such components is language or communicative training.

It should be noted that the problem of providing foreign language training to Ukrainian Armed Forces' officers with the view to their participating in international operations is a priority of the state level. This is due to the fact that the participation of Ukrainian officers in these operations confirms Ukraine's participation in global activities, recognizing its role on the global stage. Foreign language training of the Uktainian Armed Forces officers should instill the appropriate level of knowledge, skills and abilities that will allow them to perform their professional tasks, be competitive, interact with partners in international teams, etc.

Providing foreign language training for future officers of the Armed Forces of Ukraine to participate in international operations with cadets of military higher education institutions is an extremely urgent problem that requires propmt handling both at the theoretical and practical levels. With the successful solution of this problem, the preparedness of future officers of the Armed Forces to participate in international operations will contribute to the expansion of their socio-cultural space, understanding the importance of their place in it; formation of their ability to fully handle the situation, interacting in a foreign language, during professional cooperation in international peacekeeping and security operations.

The value of the conducted study is due to the fact that it ensures identifying the areas for further research. From our point of view, the promising areas of scientific enquiry are the use of educational innovations in combination with a variety of traditional methods and technologies. For example, interactive lectures can be used simultaneously with the method of mind mapping, simulation, problem methods, etc.

\section{CONFLICT OF INTERESTS}

The authors declare that there is no conflict of interest.

\section{APPENDIX}

Appendix A: Questionnaire to Determine the Main Professional Competencies to Be Possessed by Future Officers of the Armed Forces of Ukraine with the View to Participating in International Peacekeeping and Security Operations

Evaluate on the four-point scale the options for professional competencies and add on your own as desired.

1 - probably required

2 - required

3 - can do without

4 - not required

The future officer participating in the international peacekeeping operation must know the following:

Content
$\begin{array}{r}\text { The main features of the English language at all levels of the hierarchical structure (phonetic, morphological, } \\ \text { lexical, syntactic) }\end{array}$
Rules for constructing affirmative, interrogative, imperative and exclamatory sentences
Grammatical constructions and their use
Rules for reading and pronounciation of basic vocabulary on military topics
Modern terminology for armaments and equipment of the forces (countries) involved in international operations
Terminological minimum enabling professional communication in a foreign language
Peculiarities of information exchange of military, military-political and military-technical character
Common and specific features of different strategies of reading English primary sources (introductory, search,
abstract), analytical and synthetic methods of redistribution of primary sources for further rendering of its


content (plan, abstract, synopsis)

Activity algorithms of the future officer of the Armed Forces in various extreme language situations during the tasks performance

Rules for drawing up and maintaining documentation in English in accordance with the staff culture

Abbreviations and their meanings used in radiotelephone communication, radio exchange and in the daily interaction of international operations participants

Tactical signs, recalculation of calibers and American units of measurement and weights for interoperability of calculations and drawing of a situation

Features of the ethnic communication culture in English with foreign colleagues during participation in international operations

Linguistic culture, history and realias of countries and organizations where English is defined as a state or working language

Your variant

Your variant

The future officer participating in the international peacekeeping operation must have the following abilities: Content

Pronounce English sounds correctly, articulate words and phrases

Read basic authentic literature on familiar topics (military), basic texts that may contain descriptions of people, places and things

Understand statements on a number of clearly defined topics: personal and family news, public affairs of a personal and general nature, routine working issues, which contain a description of people, places or things, as well as a story about current, past or future events

Compose interrogative sentences of different types and give answers to them in keeping with the communicative situation

Work quickly and efficiently with the dictionary for the fluence of information perception an $\mathrm{d}$ the correct performance of tasks

Engage in on-the-spot conversations, which includes extended messages, as well as evaluation of information and stating an opinion as to what was heard with its justification (the statement of each partner should consist of at least 7 phrases, properly articulated)

Perform grammatical transformations in the translation process, should any translation challenges occur - to know how to apply generalization and descriptive translation

Translate texts from English into Ukrainian without the help of a dictionary and vice versa within the program language material

If need be, perform the abstract translation of military-technical and military-special texts Make concise reports and draft synopsises after briefings, meetings, official meetings

Transform the content of the previously read or listened to English-language source of regional military topics to one or two sentences, plan, summary

Find the necessary information in English in a compressed time frame

Clearly and distinctly convey information and instructions of senior management to subordinates in international operations

Work with an interpreter (in English) to engage in dialogue with local authorities and civilians to make peace under conditions of risk

Draw conclusions, select information and find specific information in more complex texts related to own professional field of activity

Your variant

Your variant

The future officer participating in the international peacekeeping operation must have the following skills:

\begin{tabular}{cc} 
Content & Grade \\
\hline High level of linguistic culture \\
Differentiation of information received in a foreign language by areas of activity \\
Summarizing and abstracting of texts on professional topics \\
Reading, listening and translating texts on countrystudy and military topics \\
\hline
\end{tabular}


Monologic and dialogic speech (sticking to the normative pronunciation and use of a wide stock of general scientific and special military vocabulary) according to the chosen profession

Adequate translation and understanding of newspaper and magazine texts on educational, professional and sociocultural communicative spheres

Communication in English with foreign colleagues in non-standard language situations in a compressed time frame High emotional resistance to activities in non-standard language situations

High speed ability to find and identify the relevant information in English in a compressed time frame

Your variant

Your variant

Date:

Your age:

Position (specialty):

\section{References}

[1] D. Druckman, G. Mueller and P. F. Diehl, (Jan. 8, 2021). Exploring the compatibility of multiple missions in un peace operations, Int Peacekeep, vol. 28, (Ahead of print). [Online].

Available: https://doi.org/10.1080/13533312.2020.1861944

[2] V. P. Fortna, "Does peacekeeping keep peace? International intervention and the duration of peace after civil war," Int Stud Q, vol. 48, no. 2, pp. 269-292, 2004.

[3] T. Donais and E. Tanguay, (Feb. 3, 2021). "Protection of civilians and peacekeeping's accountability deficit," Int Peacekeep, vol. 28, (Ahead of print). [Online]. Available: https://doi.org/10.1080/13533312.2021.1880900

[4] P. Martin, "Philippine English revisited," World Eng, vol. 33, no. 1, pp. 50-59, 2014.

[5] D. Crouse, "Languages for specific purposes in the $21 \mathrm{st}$ century," Lang Educ, vol. 8, no. 3, pp. 32-35. 2018.

[6] G. Ferguson, C. Pérez-Llantada and R. Plo, "English as an international language of scientific publication," World Eng, vol. 30, no. 1, pp. 41-59, 2011.

[7] C. Pérez-Llantada, Scientific Discourse and the Rhetoric of Globalization. London: Continuum, 2012.

[8] A. Waldvogel and D. A. S. de Souza, "Brazil's rise and Portuguese as a strategic foreign language: preparing tomorrow's military leaders," Hispania, vol. 100, pp. 289294, 2017.

[9] O. Tyron, "Psycholinguistic approach to the foreign language competence formation of future seafarers," Psychol, vol. 8, no. 4, pp. 663-675, 2017.

[10]K. Homan, (2008). Multinational Peace Support Operations: Problems and Prospects. [Online] Available: https:/www.clingendael.org/sites/default/files/pdfs/20080 000_cscp_chapter_homan_ribbelink.pdf

[11]B. Langerholc, (Feb, 14, 2011). Cohesion in Multinational Military Units. [Online] Available: https://cgsc.contentdm.oclc.org/digital/collection/p4013co $112 / \mathrm{id} / 2707 /$

[12]E. M. Blowers, "Towards a multilingual and crosscultured officer corps: A study of language and culture training programs for army ROTC cadets", Master's Thesis, Syracuse Univ., Syracuse, NY, 2017.

[13] O. V. Lemeshko, A. V. Yankovets, I. O. Bets, and I. F. Isaieva, "Peculiarities of the English language training of military administration masters," Revista Romaneasca pentru Educatie Multidimensionala, vol. 11, no. 2, pp. 160-179, 2019.

[14] S. Wa-Mbaleka, "Factors leading to limited faculty publications in Philippine higher education institutions," Int Forum, vol. 18, no. 2, pp. 121-141, 2015.

[15] C. Határ and S. Grofčíková, "Foreign language education of seniors," J Lang Cult Educ, vol. 4, no 1, pp. 110-123, 2016.

[16]A. C. Mikkelson, J. A. York, and J. Arritola, "Communication competence, leadership behaviors, and employee outcomes in supervisor-employee relationships," Bus Prof Commun Q, vol. 78, no. 3, pp. 336-354, 2015.

[17] V. Koval, Y. Polyezhayev, and A. Bezkhlibna, "Communicative competences in enhancing of regional competitiveness in the labour market," Balt J Econ Stud, vol. 4, no. 5, pp. 105-113, 2018.

[18] S. Stadler, "Intercultural competence and its complementary role in language education," In C. PérezLlantada and M. Watson Eds., Specialised Languages in the Global Village Newcastle upon Tyne: Cambridge Scholars Press, 2011, pp. 269-286.

[19]M. Jaros, "Leadership and methodology challenges in higher education: Integrating personal development, skills and competences in the space of digital systems," Glob J Inf Technol, vol. 4, no. 1, pp. 1-6, 2018.

[20] L. V. Pet'ko, "Teaching methods and the formation of professionally oriented foreign language learning environment in conditions of university," Intellect Archive, vol. 5, no. 4, pp. 73-87, 2016.

[21]A. Bocanegra-Valle, "The language of seafaring: Standardized conventions and discursive features in speech communications" Int J Eng Stud, vol. 11, no. 1, pp. 35-53, 2011.

[22] R. L. Jones-Kellogg and S. Martin, "Portuguese as a world language for future army officers," Hispania, vol. 100, no. 5, pp. 295-296, 2018.

[23] V. Bove and A. Ruggeri, «Kinds of blue: Diversity in UN peacekeeping missions and civilian protection," Brit $J$ Polit Sci, vol. 46, no. 3, pp. 681-700, 2016.

[24]P. F. Diehl and D. Druckman (eds.), Operation Success: A Comparative Analysis. Leiden: Martinus Nijhoff, 2013.

[25] L. W. Moe, "The dark side of institutional collaboration: how peacekeeping-counterterrorism convergences 
weaken the protection of civilians in Mali," Int Peacekeep, vol. 28, no. 1, pp. 1-29. 2021.

[26] K. Stewart, D. Cremin, M. Mills, and D. Phipps, (2004). Non-technical Interoperability: The Challenge of Command Leadership In Multinational Operatioms. [Online] Available: http://dodccrp.org/events/10th_ICCRTS/CD/papers/298.p df

[27] H. Albrecht, M. Bufano, and K. Koehler, "Role Model or Role Expansion? Popular Perceptions of the Military in Tunisia," Political Research Quarterly 67, Article $106591292110014,2021$.

[28]K. M. Kenkel, "Stability abroad, instability at home? Changing UN peace operations and civil-military relations in Global South troop contributing countries," Contemporary Security Policy, vol. 42, no. 2, pp. 225240, 2021.

[29] A. Holger, "Military Insubordination in Popular Mass Uprisings," Political Science Quarterly, vol. 134, no. 2, pp. 303-328, 2021.

[30] J. C. Duncheon, and J. Muñoz, Examining Teacher Perspectives on College Readiness in an Early College High School Context, American Journal of Education, vol. 125 , no. 3, pp. 453-478, 2019. [Online] Available: https://doi.org/10.1086/702731

\section{Contribution of Individual Authors to the Creation of a Scientific Article (Ghostwriting Policy)}

All authors contributed equally to the creation of the given scientific article.

\section{Creative Commons Attribution License 4.0} (Attribution 4.0 International, CC BY 4.0)

This article is published under the terms of the Creative Commons Attribution License 4.0

https://creativecommons.org/licenses/by/4.0/deed.en_US 